|| ISSN(online): 2589-8698 || ISSN(print): 2589-868X || International Journal of Medical and Biomedical Studies Available Online at www.ijmbs.info

PubMed (National Library of Medicine ID: 101738825) Index Copernicus Value 2017: 40.03 Volume 3, Issue 3; March: 2019; Page No. 27-30

\title{
PATTERN OF CO-MORBIDITIES IN CHILDREN WITH SEVERE ACUTE MALNUTRITION ADMITTED IN MTC AT M.G. HOSPITAL BHILWARA, RAJASTHAN
}

\author{
Sunil Kumar Dadhich ${ }^{1}$, Kuldeep Singh Rajpoot ${ }^{2}$ \\ ${ }^{1}$ Senior Resident, Department of Pediatrics, RVRS Medical College, Bhilwara, Rajasthan, India. \\ ${ }^{2}$ Assistant Professor, Department of Pediatrics, RVRS Medical College, Bhilwara, Rajasthan, India.
}

Article Info: Received 10 February 2019; Accepted 02 March. 2019

Cite this article as: Dadhich, S., \& Rajpoot, K. (2019). PATTERN OF CO-MORBIDITIES IN CHILDREN WITH SEVERE ACUTE MALNUTRITION ADMITTED IN MTC AT M.G. HOSPITAL BHILWARA, RAJASTHAN. International Journal of Medical and Biomedical Studies, 3(3).

DOI: https://doi.org/10.32553/ijmbs.v3i3.139

Address for Correspondence: Kuldeep Singh Rajpoot, Assistant Professor, Department of Pediatrics, RVRS Medical College, Bhilwara, Rajasthan, India.

Conflict of interest: No conflict of interest.

\section{Abstract}

Background: A round the globe nearly 20 million children below the age of five, having Severe Acute Malnutrition (SAM) and contributing to one million deaths every year in this age group. To study the pattern of co-morbidities in children having Severe Acute Malnutrition in MTC attached to a teaching hospital.

Methods: This prospective study was carried out in the MTC attached to Department of Pediatrics, M.G. Hospital Bhilwara, Rajasthan. All children between One to sixty months of age with severe acute malnutrition (SAM) admitted in the Malnutrition Treatment Centre were included. WHO criteria were followed for diagnosis and need for admissions in children suffering from severe acute malnutrition.

Results: Out of 200 children having SAM $55.00 \%$ children were having one co-morbidity, $27.00 \%$ were having two co-morbidity and $10.00 \%$ were having more than two co-morbidty.

Conclusions: It is imperative to suspect and anticipate co-morbid condition in these children. High index of suspicion for these co-morbidities is the key to reduce mortality and better outcome in children having acute severe malnutrition.

Keywords: sever acute malnutrition (SAM), malnutrition treatment corner (MTC), co-morbidity

\section{Introduction:}

A round the globe nearly 20 million children below the age of five, having Severe Acute Malnutrition (SAM) and contributing to one million deaths every year in this age group ${ }^{1}$. According to National Family Health Survey-III, conducted during 2005-2006 in India, 6.4\% of children below 60 months of age were suffering from this malady (weight-for-height less than 3SD). With the current estimated total population of India as 1100 million, it is expected that there would be about 132 million under-five children and amongst these about $6.4 \%$ or 8.1 million are likely to be suffering from SAM. In India more than 5 million children die every year as a direct or indirect result of malnutrition ${ }^{2}$. This high mortality rate in children, especially in less developed countries like ours, with complicated SAM is because of co-morbid conditions namely infections and micronutrient deficiencies ${ }^{3}$. Anticipation and early detection of some of these 
co-morbid conditions, along with preventive measures may bring down this unacceptably high mortality statistics ${ }^{3-5}$.

Due to paucity of systematic reporting of clinical and laboratory data at the time of admission or during hospital stay to identify baseline risk factors and presence of these conditions. This is not allowing doing comparative studies of the burden, spectrum and outcome of co-morbidities associated with SAM. Here we present a description of co-morbid findings in children admitted to a tertiary level hospital in central India.

\section{METHODS}

This prospective study was carried out in the MTC attached to Department of Pediatrics, M.G. Hospital Bhilwara, Rajasthan. All children between One to sixty months of age with severe acute malnutrition (SAM) admitted in the Malnutrition Treatment Centre were included. WHO criteria were followed for diagnosis and need for admissions in children suffering from severe acute malnutrition ${ }^{6,7}$. Children having obvious or suspected, congenital malformation and genetic disorder including thalassemic were excluded from this study. Complete history was obtained and general physical and systemic examination was done in each case. Demographic parameters were also noted. Apart from this clinical signs of micronutrient deficiencies were also assessed in every child. Frequencies of various co morbid conditions in study population were recorded.

\section{RESULTS}

Table 1: Socio-demographic variable of studied children

\begin{tabular}{|l|l|l|}
\hline Socio-demographic variable & No of children & Percentage \\
\hline Age group & & \\
\hline $6-11$ months & 67 & $33.5 \%$ \\
\hline $12-35$ months & 101 & $50.5 \%$ \\
\hline $36-60$ months & 32 & $16.00 \%$ \\
\hline Gender & & \\
\hline Male & 136 & $68.00 \%$ \\
\hline Female & 64 & $32.00 \%$ \\
\hline
\end{tabular}

Out of 200 children having SAM $32.00 \%$ were females and $68.00 \%$ were male. Most of the children (50.5\%) brought to MTC between 12-35 months in age.

Table 2: Pattern of co-morbid conditions in studied population.

\begin{tabular}{|l|l|l|}
\hline Co morbid condition & Number & percentage \\
\hline Acute Respiratory Infection & 110 & $55.00 \%$ \\
\hline Acute Gastrointestinal Infection & 51 & $25.50 \%$ \\
\hline Anaemia & 80 & $40.00 \%$ \\
\hline Fever & 36 & $18.00 \%$ \\
\hline Tuberculosis & 6 & $3.00 \%$ \\
\hline Skin disease & 12 & $6.00 \%$ \\
\hline
\end{tabular}

In children having SAM, Anaemia, Acute respiratory infections and acute gastrointestinal infections were the most common co-morbid conditions in our study. $55.00 \%$ of children were having ARI, $40.00 \%$ of children were having Anaemia and $25.00 \%$ were suffering from gastrointestinal infections in this study group. 
Table 3: Pattern Number of co-morbid conditions in studied population.

\begin{tabular}{|l|l|l|}
\hline Number of co-mobid & Number & percentage \\
\hline One & 110 & $55.00 \%$ \\
\hline Two & 54 & $27.00 \%$ \\
\hline More than two & 20 & $10.00 \%$ \\
\hline
\end{tabular}

Out of 200 children having SAM $55.00 \%$ children were having one co-morbidity, $27.00 \%$ were having two co-morbidity and $10.00 \%$ were having more than two co-morbidty.

\section{DISCUSSION}

Mean age of children reporting with malnutrition was similar to other studies and there was no significant sex predominance in malnourished children $^{7-9}$. Anaemia,Diarrhoea and acute respiratory infection were the three most common co morbid diseases. Previous studies have also reported that malnourished children suffer in greater proportion from bacterial gastrointestinal and respiratory infections ${ }^{10}$. In a Colombian study, $68.4 \%$ of malnourished children were suffering from diarrhoea and $9 \%$ had sepsis at the time of admission ${ }^{9}$. Two African studies also showed high incidence of diarrhoea in SAM children of $49 \%$ and $67 \%{ }^{11,12}$. Overlapping nature of protein-energy malnutrition and micronutrient deficiencies were well understood and it is seen that lack of one micronutrient is typically associated with deficiency of others ${ }^{15}$ 16. Anaemia was most common micronutrient deficiencies associated with malnutrition in our study, and this is consistent with the previous reports ${ }^{14}$. The high incidence of anaemia in these children could be due to nutritional factors as well as incidental helminthic infections. Other micronutrient deficiencies seen in this study have also been previously reported with similar prevalance $^{15}$.

\section{CONCLUSION}

Apart from nutritional rehabilitation, timely identification and treatment of co-morbidities like acute respiratory tract infection, diarrhoea, anemia and micronutrient deficiencies is also needed in malnourished children, so as to break under nutrition-disease cycle. High index of suspicion and sensitization of MTC team, towards co-morbidities is of paramount importance, to decrease mortality and to improve outcome in these less blessed children.

\section{REFERENCES}

1. International Institute for Population Studies (IIPS) and Macro International. National Family Health Survey (NFHS-3),20052006.IIPS,Mumbai,India,2007.

2. Umesh kapil, HPS Sachdev Indian Pediatrics 651 volume 47,August 17, 2010.

3. Steve Collins Treating Severe Acute Malnutrition seriously, Arch Dis. Child. 2007 May;92(5):453-461.

4. Black RE, Allen LH, Bhutta ZA, Caulfield LE, de Onis $M$, Ezzati $M$, et al. Maternal and child under nutrition: global and regional exposures and health consequences. Lancet. 2008;371:243-60.

5. Heikens GT. How can we improve the care of severely malnourished children in Africa? PLoS Med. 2007;4:e45.

6. World Health Organization (WHO) Guidelines for Inpatient Treatment of Severly Malnourished Children. WHO, Geneva, Switzerland, 2003.

7. Indian Academy of Pediatrics (IAP). IAP Guidelines 2006 for hospital-based management of severely malnourished children (adapted from WHO Guidelines). Indian Pedaitr. 2007;44:443-61

8. De Onis M, Monteiro C, Akré J, Clugston G. The worldwide magnitude of protein-energy malnutrition: An overview from the WHO global database on child growth.Bull World Health Organ. 1993;71:703-12.

9. Bernal C, Velásquez C, Alcaraz G, Botero J. Treatment of severe malnutrition in children: Experience in implementing the world health organization guidelines in 
turbo, Colombia. J Pediatr Gastroenterol Nutr. 2008;46:322-8.

10. Scrimshaw NS, SanGiovanni JP (1997) Synergism of nutrition, infection, and immunity: An overview. Am J Clin Nutr 66:464S-477S.

11. Talbert A, Thuo N, Karisa J, Chesaro C, Ohuma E, Ignas $J$, et al. Diarrhoea complicating severe acute malnutrition in Kenyan children: A prospective descriptive study of risk factors and outcome. PLoS One. 2012; 7:1.

12. Irena $A H$, Mwambazi $M$, Mulenga $V$. Diarrhea is a major killer of children with severe acute malnutrition admitted to inpatient set-up in Lusaka, Zambia. Nutrition J.2011;10:110.

13. Bhaskaram P. Measles and malnutrition. Indian J Med Res. 1995;102:195-99.

14. Ejaz MS, Latif N. Stunting and micronutrient deficiencies in malnourished children. J Pak Med Assoc. 2010;60:543-7.

15. Chainani N, Sharma $P$, Meena N, Sharma U. Pattern of vitamin deficiencies among the malnourished preschool children in ICDS blocks of Jaipur city. Indian J Matern Child Health. 1994;5:109-11. 